Aarfa Nasim ${ }^{1}$ Ravi Prakash Sasankoti Mohan ${ }^{1 *}$ Nagaraju Kamarthi ${ }^{1}$ Vijay Wadhwan ${ }^{1}$

\section{Idiopathic Bilateral Central Giant Cell Granuloma of Jaw- A Case Report and Brief Review of Reported Cases}

\begin{abstract}
:
Central giant cell granuloma (CGCG) is a benign intraosseous reactive lesion of jaw with diverse clinical and radiological behaviour pattern. It accounts for $7 \%$ of neoplastic bone lesion of jaw with 70\% occurring in mandible. CGCG was first considered as giant cell tumor mostly found in epiphyseal region of long bone having both aggressive and non-aggressive pattern. The etiology of the lesion is not defined. Multiple CGCGs of the jaw bones is very rare and, if it occurs, it is usually associated with hyperparathyroidism in majority of the cases. We report an interesting case in which a 33 year old female came with a swelling present on right side of mandible which was asymptomatic. Another swelling was present on left side which was non-evident and asymptomatic. Clinical, radiological and histopathological examination confirmed the lesions as central giant cell granuloma. Biochemical examination showed no signs of hyperparathyroidism. This report represents a very rare entity in which there is idiopathic bilateral CGCG having both aggressive and non-aggressive type of lesion.
\end{abstract}

Keywords: Giant Cells; Granuloma; Hyperparathyroidism; Mandible.
${ }^{1}$ Subharti Dental College, Meerut, India.

Correspondence to:

Subharti Dental College, Meerut, India Subharti Dental College, Swami Vivekanand Subharti University,Subhartipuram, DelhiHaridwar By-pass road, NH-58, Meerut, India. E-mail: sasan_ravi@rediffmail.com

Article received on March 7, 2017. Article accepted on March 21, 2017. 


\section{INTRODUCTION}

Central giant cell granuloma (CGCG) as introduced for the first time by Jaffe in 1953 is a reactive lesion to an intra-osseous hemorrhage, which was clinically different from a 'true' giant cell tumor of jaw with diverse clinical behaviour pattern ${ }^{1}$. It ranges from slow-growing, asymptomatic swelling to an aggressive lesion which manifests with pain. The etiopathogenesis has not been clearly established but it has been suggested that it is the result of an exacerbated reparative process related to previous trauma and intraosseous hemorrhage that triggers the reactive granulomatous process ${ }^{2}$.

The term reparative is antiquated, as CGCG causes the destruction of involved bones. The World Health Organization has defined it as "an intraosseous lesion consisting of cellular fibrous tissue that contains multiple foci of hemorrhage, aggregations of multinucleated giant cells and occasionally trabeculae of woven bone" ${ }^{3}$. There is controversy regarding its true nature whether it is a true neoplasm or a reactive response.

Clinically, CGCG occurs at any age group but most commonly seen in first three decades individual with more of female predilection. According to Whitaker and Bouquot factors such as ovarion hormone, estrogen and progesterone plays an important role in between hormonal influence and female predominance ${ }^{4}$. Lesions are more commonly located in mandible anterior to molar frequently crossing the midline. Most of the lesions in maxilla occur in the anterior region ${ }^{4}$. It is well accepted that CGCG shows diverse clinical and histopathological features.

In majority of case the lesion is asymptomatic but other signs and symptom can be seen such as facial asymmetry, impaired nasal breathing, loosening or displacement of teeth and pathologic fracture ${ }^{5}$. Radiographic pattern of CGCG present as an expansile radiolucency in which features varies from ill-defined to a well-defined, multilocular lesion ${ }^{6}$. Teeth or tooth displacement or root resorption is most commonly seen which characterize the lesion as locally aggressive ${ }^{7}$.

Based on clinical and radiological features Chuong et al and Ficarra et al classified the giant cell lesion into aggressive and non-aggressive types in which the aggressive type showed rapid growth, root resorption, parasthesia or pain with high recurrence rate $^{8,9}$. Histologically, multinucleated giant cell in cellular vascular stroma and often new bone formation are manifested. The osteoclasts like giant cell have a patchy distribution and are associated with areas of hemorrhage ${ }^{10}$.

The differential diagnosis of CGCG includes other giant cell lesion and can be distinguished based on its biological behaviour and radiographic pattern. Multiple CGCG are commonly associated with syndromes but it can be idiopathic as well. According to literature only eight cases have been reported with idiopathic origin. This case will be an addition with the reported case having both aggressive and non-aggressive lesion. According to Chuong et al. ${ }^{8}$ recurrence rate is $72 \%$ in aggressive lesion and 3\% in non-aggressive lesion.

\section{CASE REPORT}

A 33- year- old middle- aged woman reported to the Department of Oral Medicine and Radiology of our institution with a noticeable swelling on the right lower side of face from past 7 months (Fig. 1). Swelling had gradually increased in size since then. Initially the swelling was small and gradually attained the present size with no treatment done. There was no past medical or dental history.

On extra-oral examination, swelling was evident on right side body of mandible with diffuse border and erythematous overlying skin extending $1 \mathrm{~cm}$ posterior to right commissural region of lip to $4 \mathrm{~cm}$ anterior to ramus of mandible antero-posteriorly and supero-inferiorly

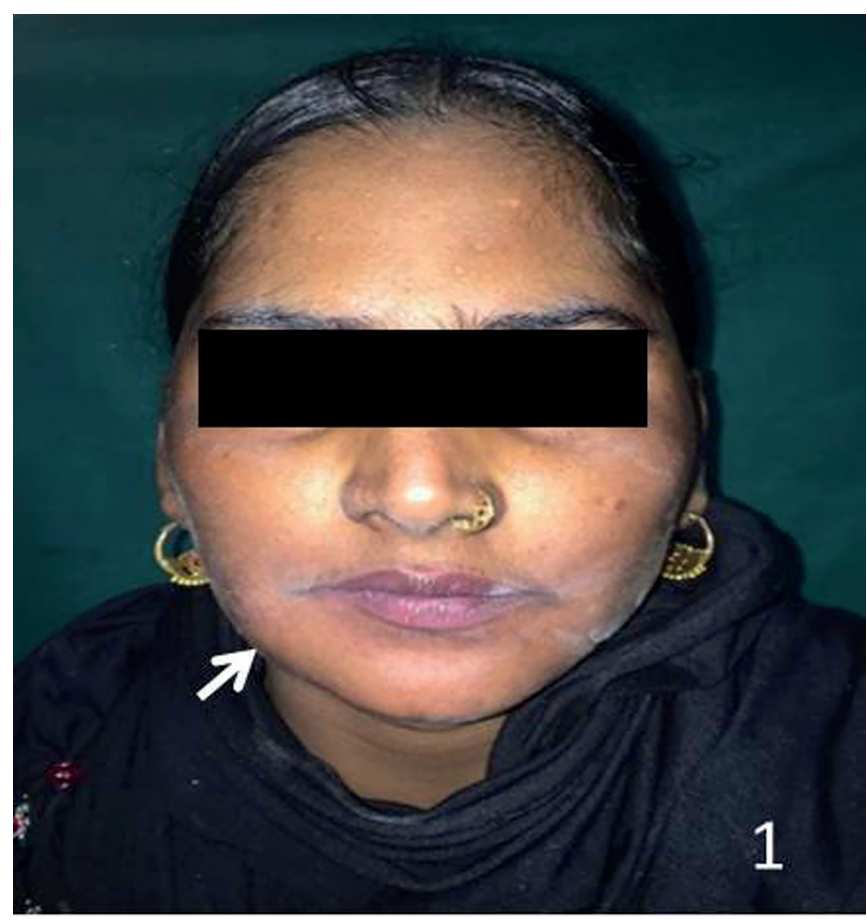

Figure 1. Swelling involving right side of mandible. 
involving level of right commissural lip to the lower border of mandible (Fig. $2 \mathrm{~A}$ and B).

On palpation swelling was non-tender and afebrile. The left side swelling was not evident. Lymph nodes were non-palpable. On Intra oral examination, we noticed buccal cortical plate expansion on both side of the jaw in the premolar- molar region (Fig. 3). On palpation, swelling on right side was firm in consistency whereas the other swelling on left side was bony hard. Swelling on the right side was fixed painless mass having diameter of $2.5 \times 3 \mathrm{~cm}$ with slight lingual expansion and on left the swelling was bony hard and non-tender having $1.5 \times 2 \mathrm{~cm}$ diameter.

Electric pulp testing revealed that the teeth involved with the swelling were vital except $45 \& 46$ and nerve vitality was not disturbed. Radiographic examination was carried out in which panoramic radiograph on right side unveiled a well- defined osteolytic bone lesion with unilocular radiolucency involving 43, 44, $45 \& 46$ regions associated with root resorption in $45 \& 46$. On left side an ill- defined mixed radiolucent- radiopaque lesion with
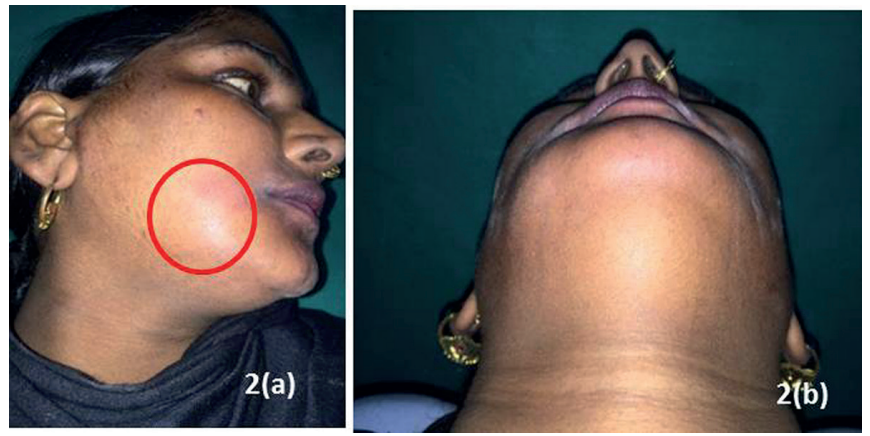

Figure 2. (A and B). Swelling present on right side with erythematous overlying skin.

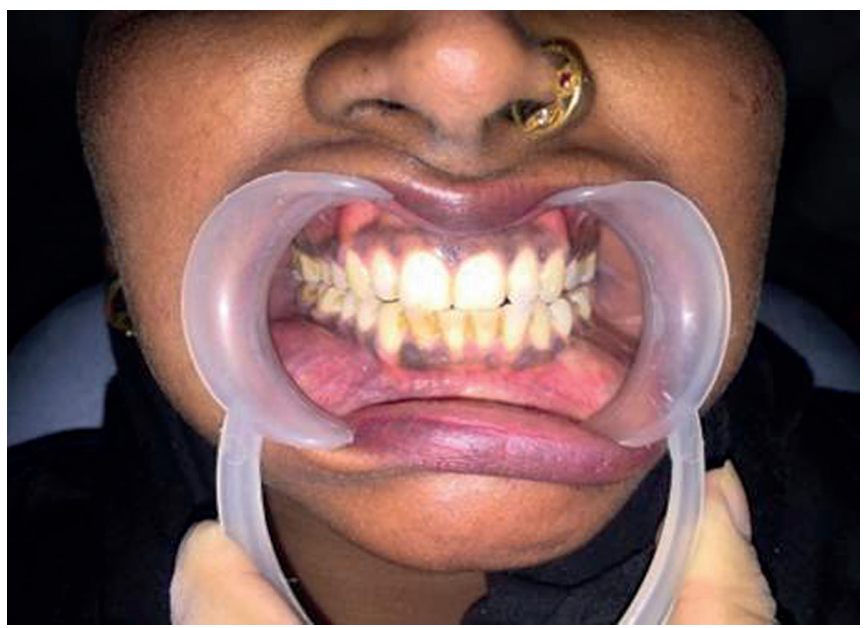

Figure 3. Buccal cortical expansion on both sides. less of destruction was appreciable in between $34 \& 35$ drifting both the roots distally on opposite direction from its normal position (as shown in Fig. 4).

Further, cone beam computed tomography showed large expansile destructive radiolucent lesion on right side with erosion and no evidence of cortication having $29 \times 24 \times 20 \mathrm{~mm}$ size and root resorption seen in 44, 45, 46. An expansile mixed radiolucent -radiopaque lesion was seen on left side with intact cortication and less of destruction having $15 \times 8 \times 5 \mathrm{~mm}$ size extending more towards buccal aspect drifting the roots of 34 and 35 (Fig. 5A-E). Based on clinical and radiological findings, differential diagnosis of CGCG, hyperparathyroidism, fibrous dysplasia, ossifying fibroma, Paget's disease and odontogenic fibroma could be made.

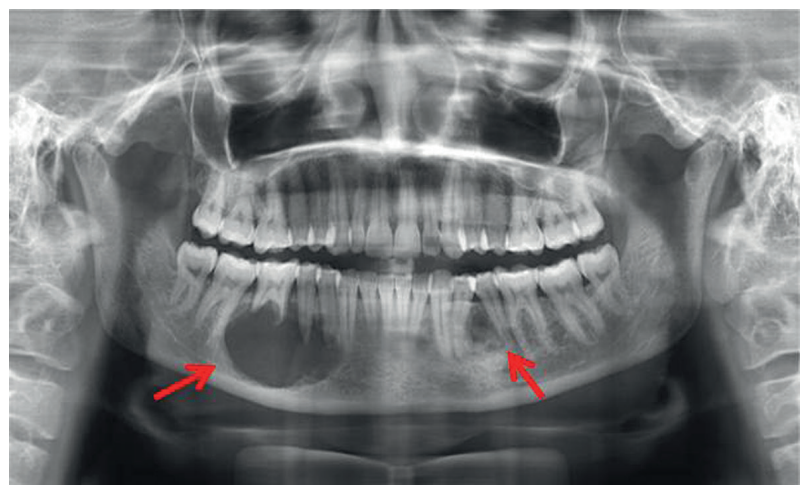

Figure 4. Panoramic radiograph showing lesion on both right and left side.
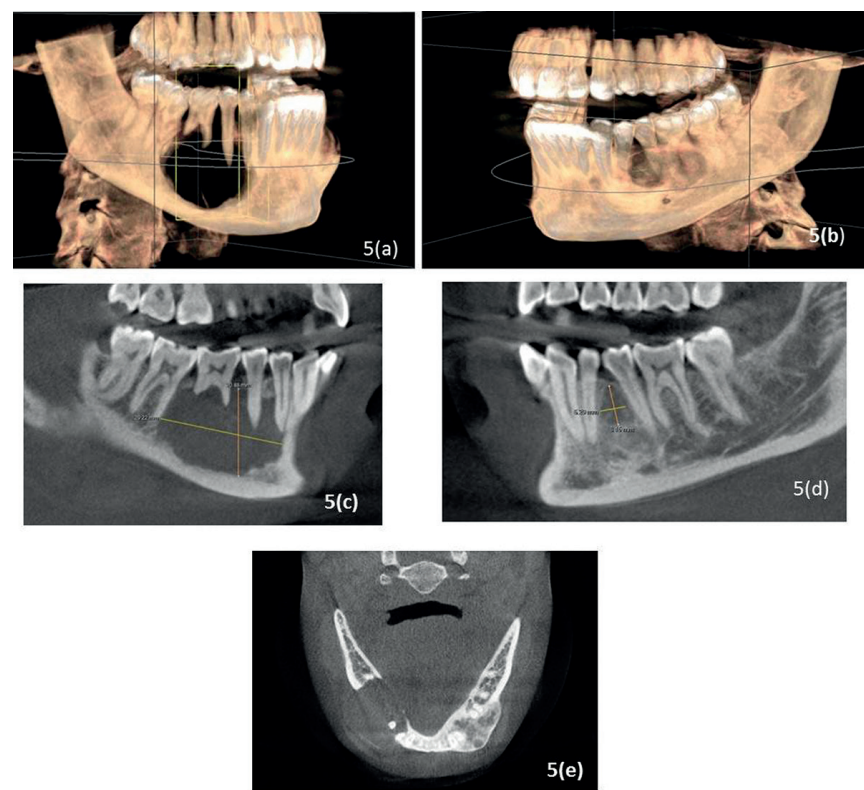

Figure 5 (A-E). Osteolytic destructive expansile radiolucent lesion on right side and root resorption seen in relation to 45,46 . Osteolytic mixed lesion on left with thinning of cortical plate drifting the roots of 34 and 35. 
Further investigation was carried out to rule out the features of hyperparathyroidism. Biochemical investigation such as serum calcium, phosphorous and serum alkaline phosphatase and PTH level showed normal limits. Lateral skull and hand and wrist radiograph was done but revealed no result of demineralization (as shown in Fig. 6).

Incisional biopsy was carried out from both the side in which there was benign fibroblast matrix with presence of multinucleated giant cells of variable size, number and distribution. Hemorrhagic areas were evident therefore confirming the diagnosis of multiple central giant cell granulomas (Fig 7A and B). Treatment given was intralesional corticosteroids in a weekly dose of triamcinolone acetonide $10 \mathrm{mg} / \mathrm{ml}$ and $0.5 \%$ lignocaine in $1: 1$ ratio in both the lesion since last 6 weeks. Surgical curettage was planned for the lesion present on right and left side.

\section{DISCUSSION}

The central giant cell lesion of jaw is one of the rare benign tumors that accounts for $7 \%$ of tumors in
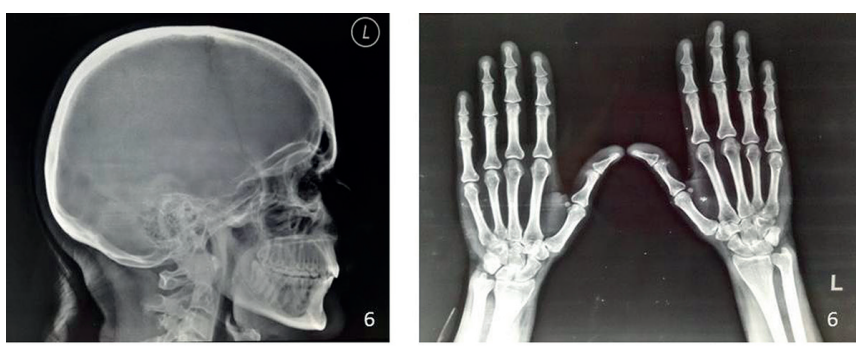

Figure 6. Normal lateral skull and hand and wrist radiograph with no evidence of demineralization.
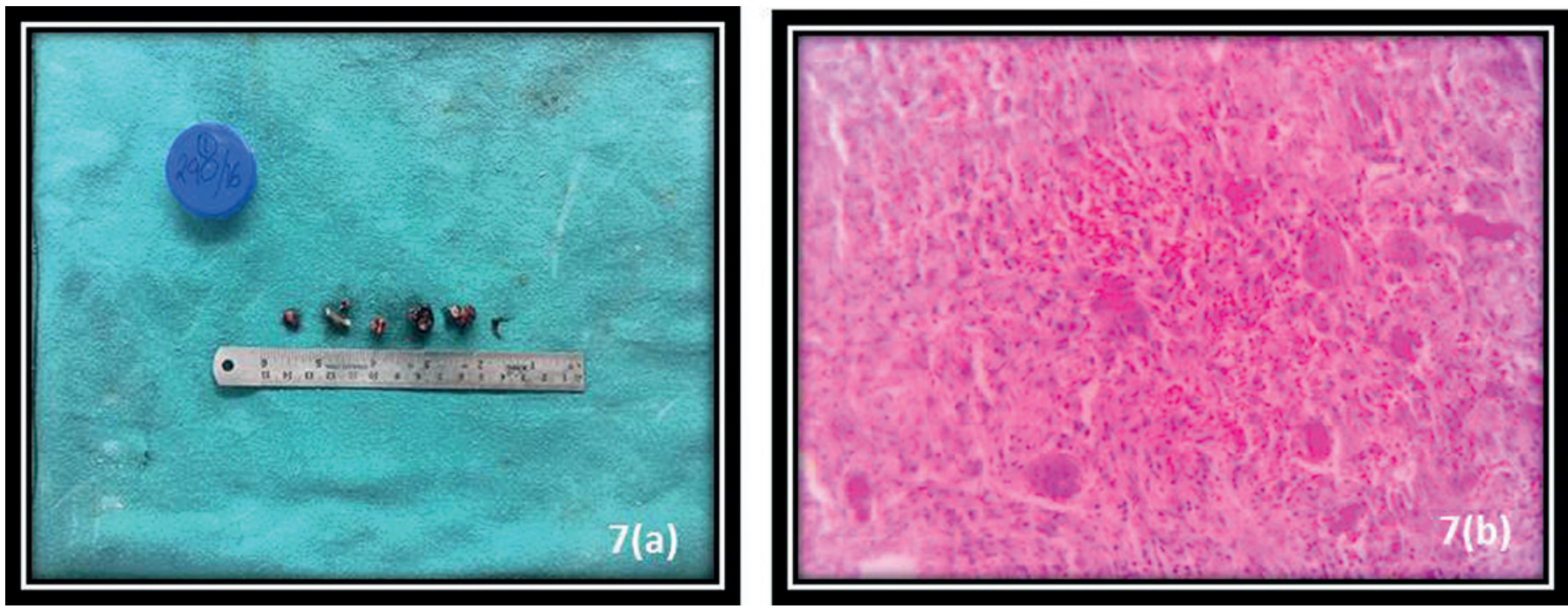

Figure 7 (A and B). Incisional biopsy specimen multiple bits of soft tissue specimen which were brownish black in color measuring about $1 \mathrm{x}$ $0.5 \times 0.5 \mathrm{~cm}$ in dimension. Photomicrograph (H\&E,X40) of the section showing benign fibroblast matrix with variable number of giant cell and hemorrhagic content. both maxilla and mandible ${ }^{11}$. It can be classified as a reactive proliferative disease with unknown etiology having typical histological features, dynamic biologic characteristic and variable clinical pattern. According to different authors the giant cells are derived from proliferating multinucleated cells associated with the resorption of deciduous tooth roots, from fusion of endothelial cells of capillaries, fibroblast, or monocytes/ macrophage lineage ${ }^{12}$.

The multinucleated giant cells that are prominently seen in CGCG are not considered as the primary proliferating tumor cells. The giant cell of CGCG are derived from subset of mononuclear phagocytes which differentiate into mature giant cell under the influence of receptor activator of nuclear factor $\kappa \beta$ ligand (RANKL) expressing, proliferating spindle shaped (osteoblast like) stromal cells. These cells are slightly modified osteoclasts ${ }^{13}$.

CGCG are usually unifocal but can be multifocal with the possibility of having some form of inherited syndrome or systemic disease like brown's tumor of hyperparathyroidism, cherubism or Noonan's syndrome or any other fibro-osseous lesion. CGCG are osteoclast rich tumors that are histopathologically indistinct from cherubism and Noonan's syndrome ${ }^{14}$. Carvalho et al reported a case in which somatic mutation in $\mathrm{SH}_{3} \mathrm{BP} 2$ that had been identified in one individual with CGCG. These findings open a new window to investigate the possible relationship between the pathogenesis of the cherubism and $\mathrm{CGCG}^{15}$. The possible syndromes associated with multiple CGCG are presented in tabulated form with their clinical signs (Table 1). 
Table 1. Syndromes associated with central giant cell granuloma.

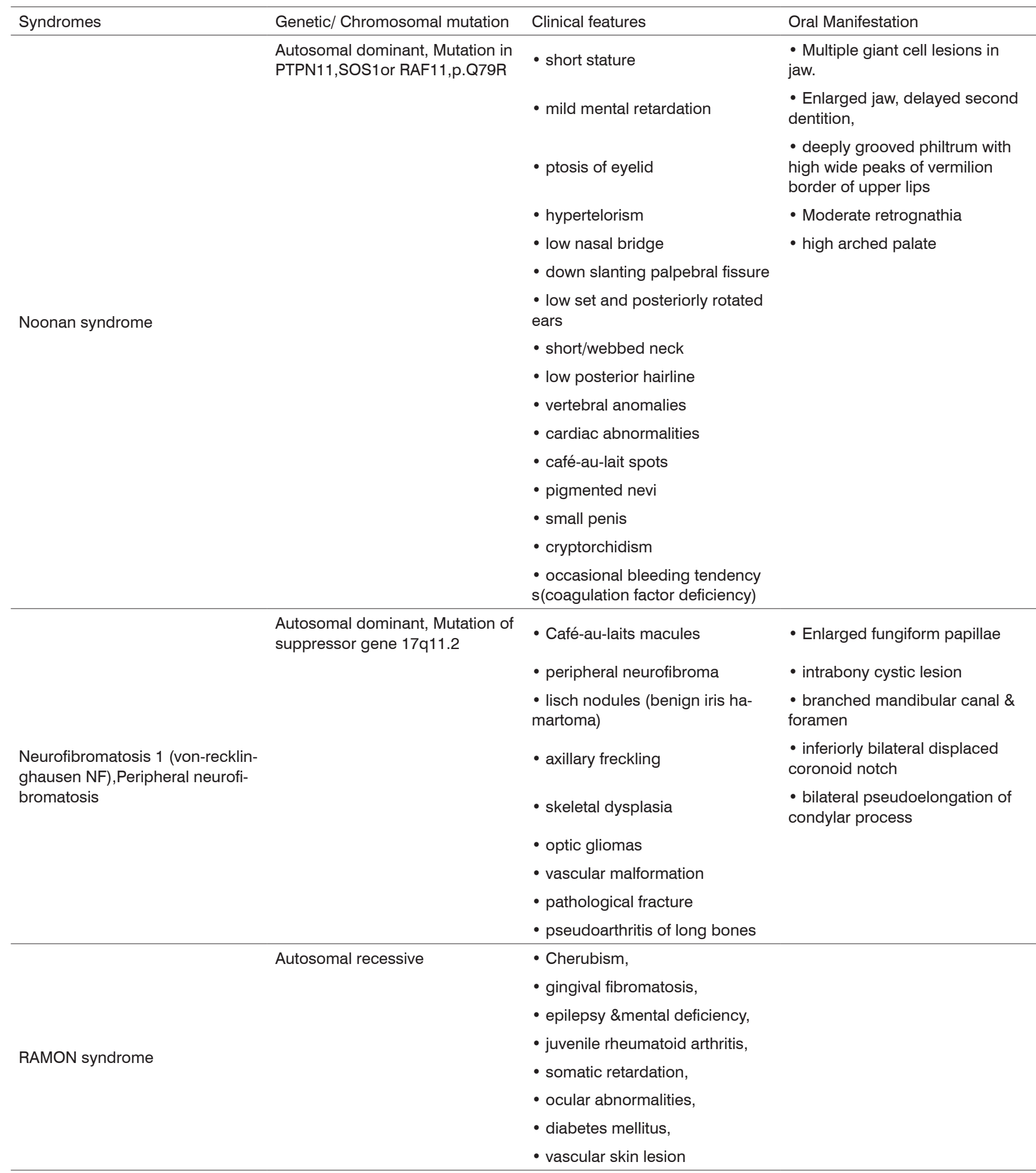

In our case there were no signs of abnormality seen related to any syndromes and patient was having normal PTH level effectively excluding the possibility of hyperparathyroidism giving the diagnosis of multiple CGCG. In literature till now only 8 cases have been reported including the present case as ninth one as shown in Table 2. 
Table 2. Reported cases of multiple central giant cell granuloma of the maxillofacial region.

\begin{tabular}{lcc}
\hline Authors & Age/Gender & Location \\
\hline Davis and Tideman (1977) & $31 / \mathrm{F}$ & Right mandibular body, left maxilla \\
Cassatly et al. (1988) & $27 / \mathrm{F}$ & Parasymphysis and mandibular body \\
Smith et al. (1990) & $41 / \mathrm{F}$ & Right mandibular ramus, left maxillary sinus, nasal bone, orbit, and right maxillary sinus \\
Wise and Bridbord (1993) & $23 / \mathrm{M}$ & Left mandibular body, left and right nasomaxillary areas \\
Wilson et al. (2007) & $35 / \mathrm{F}$ & Left maxilla and right mandible \\
Orhan et al. (2010) & $12 / \mathrm{F}$ & Right and left mandibular ramus \\
Kang et al. (2010) & $17 / \mathrm{M}$ & Right maxilla, bilateral posterior mandible \\
Moghadam et al. (2013) & $22 / \mathrm{M}$ & Right and left mandibular ramus \\
Present case, 2017 & $33 / \mathrm{F}$ & Right and left body of mandible \\
\hline
\end{tabular}

CGCG has varied clinical and radiological behaviour pattern which are divided into two categories: aggressive and non-aggressive type. Aggressive lesions are usually seen in younger patients that are painful, grows rapidly, larger overall, often cause cortical perforation, root resorption, and have tendency to recur. Non-aggressive lesion which are usually slow growing and asymptomatic and do not show cortical perforation or root resorption with less chances of recurrence ${ }^{16}$. In our case right lesion showed aggressive behaviour and left lesion showed non- aggressive characteristics.

The radiological features of CGCG described in the literature are variable. It changes with the size of the lesion. Small lesions usually appear to be unilocular radiolucent and deprived of internal bone septa. However, large lesions usually appear to be multilocular radiolucent and wispy like bony septa in this area ${ }^{17}$. An imaging feature that has been associated with CGCG, is the presence of a subtle granular bone pattern at the periphery of the expanded bone ${ }^{13}$.

According to Kaffe et al. ${ }^{18} 51 \%$ of CGCG are multilocular, $44 \%$ were unilocular, $5 \%$ were not loculated and $68 \%$ of the multilocular lesion were in the mandible. Root resorption was seen in $24 \%$ male patient and $6 \%$ female patient. in our case aggressive lesion showed unilocular radiolucent appearance and non-aggressive lesion showed mixed pattern. The differential diagnosis that could be made with the clinical and radiological pattern of CGCG (is given in Table 3).

CGCG represent itself with two major histological features with first having highly cellular fibroblastic stroma with plump spindle shaped cells with high mitotic rate and vascular density. The second main feature include prominent multinucleated giant cells throughout the fibroblastic stroma, distributed irregularly and often located numerously around areas of hemorrhage. The cell size is variable with number of nuclei ranging from few to several dozen. As cell origin is not known both aggressive and non-aggressive appear same histologically.

Management of CGCG includes surgical curettage with or without medical management. Medical therapies include intralesional corticosteroids, calcitonin injections and interferon alpha therapy. They are alternatives therapies used before surgical treatment. In 1988 , Jacoway et al. ${ }^{19}$ first reported the treatment of CGCG with intralesional corticosteroid injections. Four patients were included in the study and a weekly injection of triamcinolone acetonide was given into the lesion over a period of 6 weeks. Complete resolution was seen in three patients while additional surgical management was vital in 1 patient.

Other authors also gave encouraging results with corticosteroid injections. In 1994, Kremer et al. in the study administered triamcinolone $10 \mathrm{mg} / \mathrm{mL}$ and lignocaine $0.5 \%$ in $1: 1$ ratio once in a week for 5 weeks. Patients were followed up for 3 years with no remission. Similar concentration was used by Rajeevan et al. and patients were followed up for 10 months with no recurrence.

It is hypothesized that the extracellular production of bone resorption mediating lysosomal proteases by the giant cells is inhibited and steroids induce apoptosis of osteo-like cells ${ }^{20}$. It appears to work more successfully in unilocular lesions than multilocular lesions and is contraindicated in pregnant and immunosuppressive patients ${ }^{19}$. In the present case injection of triamcinolone $10 \mathrm{mg} / \mathrm{mL}$ and lignocaine $0.5 \%$ in $1: 1$ ratio once in a week was being administered and the patient is still undergoing treatment. 
Table 3. Differential diagnosis of CGCG

\begin{tabular}{|c|c|c|c|}
\hline Differential diagnosis & Clinical features & Radiological finding & Treatment \\
\hline Hyperparathyroidism & $\begin{array}{l}\text { mean age } 30-60 \text { years, female, mul- } \\
\text { tiple within a single bone, it could be } \\
\text { associated with hereditary syndrome } \\
\text { with one as fibro-osseous lesion }\end{array}$ & $\begin{array}{l}\text { Subtle erosion of bone from } \\
\text { subperiosteal surface of pha- } \\
\text { langes of hand,osteitis fibrosa } \\
\text { cystica,Demineralization and thin- } \\
\text { ning of cortical boundaries,change } \\
\text { in trabeculae, brown's tumor on later } \\
\text { stage, loss of lamina dura }\end{array}$ & $\begin{array}{l}\text { Surgical removal of causative para- } \\
\text { thyroid adenoma }\end{array}$ \\
\hline
\end{tabular}

\begin{tabular}{cccc}
\hline Ossifying fibroma & $\begin{array}{c}\text { Occur at any age more common } \\
\text { in young adult, female are more } \\
\text { commonly affected, asymptomatic, } \\
\text { displacement of teeth occur, rapid } \\
\text { growth result in deformity of jaw. }\end{array}$ & $\begin{array}{c}\text { Mandible mostly affected inferior to } \\
\text { premolar and molar, having mixed } \\
\text { radiolucent-radiopaque pattern }\end{array}$ & Surgical enucleation or resection \\
\hline Paget's disease & $\begin{array}{c}\text { Later middle and old age, males are } \\
\text { commonly affected, affected bone } \\
\text { is enlarged and deformed, elevated } \\
\text { serum alkaline phosphatase and } \\
\text { hydroxyproline in urine. }\end{array}$ & $\begin{array}{c}\text { Maxilla is mostly affected, oc- } \\
\text { cur bilaterally, have three stages } \\
\text { radiolucent-resorptive stage, gra- } \\
\text { nular, rounded-radiopaque patch of } \\
\text { abnormal bone giving cotton wool } \\
\text { appearance }\end{array}$ & $\begin{array}{c}\text { Surgical excision, medical } \\
\text { management with calcitonin, }\end{array}$ \\
\hline
\end{tabular}

\section{CONCLUSION}

We conclude this case as a very interesting case in which the patient was having bilateral CGCG in mandible with idiopathic origin. In literature there are several reports published on multiple CGCG associated with hyperparathyroidism or any other syndromes. Here we represent a case having no such abnormality and involving both aggressive and non-aggressive type of lesion. Another unique feature seen radiographically was that the lesion was unilocular having both radiolucent and mixed type.

\section{REFERENCES}

1. Jaffe HL. Giant cell reparative granuloma, traumatic bone cyst and fibrous (fibro-osseous) dysplasia of the jawbones. Oral Surg Oral Med Oral Pathol. 1953;6:159-75.

2. Kaur M, Singh J, Saxena S. Central Giant Cell Granuloma of Maxilla: A Case Report And Literature Review. Int J Clinic Dent Sci. 2012;3:82-6.

3. World Health Organization/International Agency for Research on Cancer; Barnes L, Eveson JW, Reichart P, Sidransky D, eds. Pathology and Genetics - Head and Neck Tumours. Lyon: 1ARC Press; 2005.

4. Whitaker SB, Bouquot JE. Estrogen and progesterone receptor status of central giant cell lesions of the jaws. Oral Surg Oral Med Oral Pathol. 1994;77:641-4.
5. Ustündağ E, Iseri M, Keskin G, Müezzinoğlu B. Central giant cell granuloma. Int J Pediatr Otorhinolaryngol. 2002;65:143-6.

6. Cohen MA, Hertzanu Y. Radiologic features, including those seen with computed tomography, of central giant cell granuloma of the jaws. Oral Surg Oral Med Oral Pathol. 1988;65:255-61.

7. Whitaker SB, Waldron CA. Central giant cell lesions of the jaws. A clinical, radiologic, and histopathologic study. Oral Surg Oral Med Oral Pathol. 1993;75:199-208.

8. Chuong R, Kaban LB, Kozakewich H, Perez-Atayde A. Central giant cell lesions of the jaws: a clinicopathologic study. J Oral Maxillofac Surg. 1986;44:708-13.

9. Ficarra G, Kaban LB, Hansen LS. Central giant cell lesions of the mandible and maxilla: a clinicopathologic and cytometric study. Oral Surg Oral Med Oral Pathol. 1987;64:44-9.

10. Rosai J. Ackerman's Surgical Pathology. Volume 1. $8^{\text {th }}$ ed. St. Louis: CV Mosby; 1996. p. 259-60.

11. Triantafillidou K, Venetis G, Karakinaris G, Iordanidis F. Central giant cell granuloma of the jaws: a clinical study of 17 cases and a review of the literature. Ann Otol Rhinol Laryngol. 2011;120:167-74.

12. Reichart PA, Philipsen HP. Odontogenic Tumors and Allied Lesions. London: Quintessence Publishing; 2004. p. 319-30.

13. Liu B, Yu SF, Li TJ. Multinucleated giant cells in various forms of giant cell containing lesions of the jaws express features of osteoclasts. J Oral Pathol Med. 2003;32:367-75.

14. Hongal BP, Joshi P, Kulkarni V, Baldawa P. Central giant cell granulomas of the jaws: A Review Of The Literature With Its Emphasis On Differential Diagnosis On Related Lesions. Int J Contemp Dent Med Rev. 2015;010115. 
15. Carvalho VM, Perdigão PF, Amaral FR, de Souza PE, De Marco L, Gomez RS. Novel mutations in the SH3BP2 gene associated with sporadic central giant cell lesions and cherubism. Oral Dis. 2009;15:106-10.

16. Whitaker SB, Waldron CA. Central giant cell lesions of the jaws. A clinical, radiologic, and histopathologic study. Oral Surg Oral Med Oral Pathol. 1993;75:199-208.

17. Güngörmüs M, Akgül HM. Central giant cell granuloma of the jaws: a clinical and radiologic study. J Contemp Dent Pract. 2003;4:87-97.
18. Kaffe I, Ardekian L, Taicher S, Littner MM, Buchner A. Radiologic features of central giant cell granuloma of the jaws. Oral Surg Oral Med Oral Pathol Oral Radiol Endod. 1996;81:720-6.

19. Jacoway JR, Howell FV, Terry BC. Central giant cell granuloma: an alternative to surgical therapy. Oral Surg Oral Med Oral Pathol Oral Radiol Endod. 1988;66:572.

20. Harris M. Central giant cell granulomas of the jaws regress with calcitonin therapy. Br J Oral Maxillofac Surg. 1993;31:89-94. 